\title{
Legal Protection of Unskilled Workers from Indonesia in ASEAN Countries
}

\author{
Dodik Setiawan Nur Heriyanto ${ }^{1}$ \\ \{dodiksetiawan@uii.ac.id ${ }^{1}$ \} \\ Faculty of Law, Universitas Islam Indonesia, Yogyakarta, Indonesia ${ }^{1}$
}

\begin{abstract}
Migrant workers are a person or group of people who move from their country to another country to get a decent living. However, in reality, due to the lack of strict regulations, there are still unskilled migrant workers from Indonesia who work in other countries, especially in Southeast Asia. The low quality of unskilled workers causes them to be the target of their employers' anger and often become victims of human rights violations. With the normative research method, this study concludes that Indonesia already has rules regarding the limits on sending skilled workers from Indonesia. Its effective implementation is needed, especially the imposition of sanctions to unscrupulous labor service providers who commit illegal acts to pass them so they can work abroad. In addition, ASEAN member countries can develop a regulatory framework to provide legal protection to unskilled workers in their regions.
\end{abstract}

Keywords: unskilled worker, legal protection, ASEAN.

\section{Introduction}

ASEAN is a regional organization that was founded on August 8, 1967, the existence of ASEAN was indicated by the signing of the Bangkok Declaration in 1967. The birth of the Bangkok Declaration directly binds members to agree to take big steps in the process of community development integrated into cooperation in in the political, economic and regional stability sectors, the objectives of the establishment of ASEAN are detailed in the Bangkok Declaration [1].

In its development, ASEAN economic cooperation leads to the formation of the ASEAN Economic Community [2], the formation of the ASEAN Economic Community, better known by the acronym AEC, was produced from the 9th ASEAN Summit in Bali in 2003 which is better known as the Bali Concord II. An important event from this meeting is the birth of three pillars which aim to increase cooperation between ASEAN member countries and also increase economic growth. The three pillars are the ASEAN Security, the ASEAN Sociocultural Community, and the ASEAN Economic Community [3].

At this time, ASEAN becomes a single market and international production base by providing freedom of movement of goods, services, investment, capital and experienced workers. It seems that the existence of this workforce is able to increase the economic growth of both the originating and receiving countries [4]. Thus, ASEAN countries currently have a more varied workforce, especially in terms of expertise and professional level. The variety of professionalism requires a clear guide in order to create global standardization. 
In supporting this activity, AEC has prepared a blueprint that discusses special arrangements for skilled workers (skilled workers), namely personnel who have special knowledge, skills and expertise in their fields obtained through education and work experience. ASEAN countries have agreed on several Mutual Recognition Arrangements (MRAs) which are recognition of the results of assessments such as tests or certificates for professionals [5]. The problem is that some of the existing workers are unskilled workers (unskilled workers), while the MRA itself has determined the standards for sending labor between countries. Seeing the standards set by the AEC is of particular concern for ASEAN members in protecting the rights of their workers [6].

This special attention to migrant workers was addressed by the 12th ASEAN summit held in Cebu, Philippines on January 13, 2007, ASEAN leaders signed the ASEAN Declaration on the Protection and Promotion of the Rights of Migrant Workers. Protection and Promotion of the Rights of Migrant Workers) or also known as the Cebu Declaration. This is based on a shared awareness of the contribution of migrant workers to society and the economy of both sending and receiving countries [7].

Migrant workers or what are known as migrant workers are defined as people who migrate for work/as seasonal workers from their home country to another country and usually that person cannot stay forever in the country where they work [7]. In other words, the definition of a migrant worker itself provides opportunities for citizens of each ASEAN member country to work outside their home country, without any obstacles from the country to be targeted. From the above explanation, it can be concluded that labor migration between countries is now starting to develop, therefore several legal regulations are needed to safeguard its existence.

The existence of this migration of migrant workers poses challenges for both receiving and sending countries because they have to balance domestic and labor market needs based on the views and needs of the receiving country, there are also several rights and protections that will be given to migrant workers as the main aspects in make rules or policies regarding this matter [8]. Sending countries, for example, must also balance the government's attention to the workers they send when making their policies. Many concerns arise between the two countries in making rules or policies that they will apply.

It is appropriate that the legal protection for migrant workers is based on the benefits obtained from the two parties of ASEAN member countries which should be able to meet the needs in terms of legal protection of and/or against workers. This can be seen from several cases that occurred during the sending and receiving activities, even the treatment of the countries of origin and receiving countries to migrant workers, which turned out to be a lot of injustice. This is based on several cases that befell workers, especially Indonesians who work for ASEAN member countries, who receive unfair treatment which requires them to be tortured or to carry out acts of self-defense which cause our workers to have legal problems' [9].

Before going further, we can justify that because of the unfair treatment given to workers that is purely due to violence at work, it seems that we need to look further about the readiness or preparation of the workforce itself. This is because of the several cases that have occurred, some of which are due to the unskilled workforce in carrying out their role as workers. Unskilled workers can be defined as workers who have no skills or skills, do not attend special training, and are not highly educated, perhaps only having graduated from formal education (elementary school, junior high school, or high school)[10][11]. Thus, this group of unskilled workers usually only becomes domestic servants, construction workers or office boys, this is because some of them do not have certificates as laborers who have attended training or 
training and even some of them are illegal workers who do not have the opportunity to work in the country of origin.[12]

\section{Literature Review}

Migrant labor is the process of moving someone from one place to another in order to get a job and decent wages. Generally, these labor migrants are international in nature where migration is carried out between countries in order to find work. The main factor that becomes an important reason for this migration is due to the inequality of wage levels that occur globally. Migration of workers from sending countries to receiving countries makes receiving countries cheap labor while sending countries benefit from the flow of money transfers [13].

The International Labor Organization (ILO) defines a migrant worker as someone who has migrated, or has migrated, from one country to another, with a picture of being employed by someone other than himself, including anyone who is accepted regularly, as a migrant, for a job.[14] A similar definition is stated in the International Convention on the Protection of the Rights of All Migrant Workers and Members of Their Families in 2000 that the term "migrant worker" refers to a person who is to be engaged, is engaged, or has been engaged in a remunerated activity in a State which he or she is not a national [15].

There are three important factors that cause workers to move from their home countries to countries that provide good wages, such as: demand pull (because of the increasing demand of workers in other countries), supply push (because of no availability employment opportunity ih their own country), and network (because of the existing connection i.e. family relations motivate them to migrate to other countries) [16]. Moreover, the current economic globalization has become a trigger for the migration of workers from their home countries to other countries. This is because in globalization, trade in goods and services, transfer of capital, transportation networks, and exchange of information moves freely between countries. The flow of migrant workers is increasing according to the needs of the labor market amidst growing economic competition between countries [17].

From an economic perspective, the contribution of migrant workers can be obtained through the amount of remittances (money, goods, and expertise) sent. This will be more meaningful if the remittances are seen in a broader context, not only in the form of money, but also in nonmaterial forms, such as new ideas, knowledge of modern technology, enthusiasm for work, special skills, and work discipline. Remittances, both in the form of cash and non-money, are believed to have a positive potential for regional development. Many studies explain how remittances play a role in improving household economies.

\section{Methods}

The type of legal research used is a type of normative legal research that focuses on the legal protection of unskilled workers from Indonesia in ASEAN countries. This research is an attempt to find out whether there is a legal solution related to the problems faced by unskilled workers who work in ASEAN countries. There are two approaches to be used in this research, namely: statue approach, which is a method of assessing legal issues through a statutory approach. The laws and regulations here are in the form of binding international agreements. Comparative approach, which is a comparative legal study method. In this case, the researcher 
will compare several legal rules in ASEAN countries related to the protection of migrant workers.

\section{Result and Discussion}

\subsection{Regulation related Unskilled Workers in Indonesia}

The existence of the ASEAN Economic Community has resulted in various trade sector liberalizations which include liberalization in trade in goods, services, investment, and mobility of labor production factors. All this liberalization will not only have implications for the movement of goods, services and investment, but will also have an impact on labor conditions that will be free to work in ASEAN member countries. This is due to easy access for workers from other countries to compete for jobs with local workers and vice versa, workers from Indonesia can also enter member countries in ASEAN.

The distribution of Indonesian workers abroad is an alternative effort to solve the problem of unemployment and scarcity of job opportunities in the country. For that in terms of marketing, the provision of quality manpower, protection and welfare of the workforce needs to be constantly improved, namely by issuing laws and regulations relating to the placement of Indonesian workers abroad. With the existence of these laws and regulations, it can become a legal basis and guidelines for Indonesian workers who will participate in the AEC.

Indonesian workers are all Indonesian citizens who are eligible to work abroad in an employment relationship for a specified period of time and receive a work wage. The implementation of the placement of Indonesian migrant workers abroad consists of the government, Private Placement Institution of Indonesian Migrant Workers (PPTKIS) which was formerly known as PJTKI (Indonesian Employment Service Company), and companies for their own interests. Meanwhile, Indonesian migrant workers service users are government agencies, private legal entities, and/or individuals in destination countries who employ Indonesian migrant workers. The placement of Indonesian migrant workers outside the country can only be done by the Government on the basis of a written agreement between the government and the user country of the Indonesian migrant workers (destination country).

To regulate the placement of Indonesian migrant workers, the government has issued Law No.39 of 2004 concerning the Placement and Protection of Indonesian Workers Abroad.[18] Placement implementation requires cooperation with related parties at the district or provincial level for monitoring its implementation. Thus, the role of the Social, Manpower and Transmigration Offices in each region is needed in the placement of Indonesian workers abroad to ensure the legality of the existence of Indonesian migrant workers and PPTKIS. The strategy set by the Central Government is then implemented by all Manpower Offices throughout Indonesia. The regulations that have been stipulated in Law Number 18 of 2017 concerning the Protection of Indonesian Migrant Workers become a basis for all activities that the Social, Manpower and Transmigration Office carries out all activities for placing Indonesian migrant workers abroad [19].

The placement of Indonesian migrant workers is usually followed by skilled and educated workers. They really follow procedures and ensure legal protection by both countries. However, for unskilled workers, they usually follow legal or illegal procedures or what we often hear as illegal migrant workers. Legal unskilled workers who do not directly go to the government, usually through PPTKIS, are private Indonesian workers who involve the private sector to absorb or take part in providing information about job vacancies to TKI to work abroad. These PPTKIS work under BP2MI (Indonesian Migrant Workers Body) and usually register through the local authority.[20] Generally, the flow of labor in the ASEAN region is divided into 5 (five) corridors: from Myanmar to Thailand, from Indonesia to 
Malaysia, from Malaysia to Singapore, from Laos to Thailand, and from Cambodia to Thailand.

Thailand is the destination country for migrant workers from other ASEAN countries to work. Meanwhile, Myanmar, Indonesia, Malaysia, Laos and Cambodia are the countries that supply a large number of intra-ASEAN workers. Despite tightening checks in the border area between ASEAN members and tight labor recruitment, the number of unskilled workers remains unstoppable. Based on existing data, unskilled Indonesian workers work in the plantation industry in Malaysia [21].

The domination of migrant workers in the ASEAN region is unskilled migrant workers. Lack of knowledge and education for migrant workers actually harms unskilled migrant workers. In fact, to compete in the ASEAN Economic Community, workers not only need high abilities, but must also be accompanied by certification in recognition of expertise. However, the certification that has been carried out so far, especially in Indonesia, is often confusing because of the convoluted process and sometimes it can be obtained by giving an amount of money in an illegal way. Hence, it is necessary to strive for a legal policy that must be adhered to by ASEAN countries to apply minimum labor standards including equipping workers in the field of adequate education and carrying out credible expertise certification.

\subsection{The Urgency of Binding Regional Rules (Hard Law) in Providing Protection for Unskilled Migrant Workers in ASEAN}

The implementation of the 2015 ASEAN Economic Community is a challenge in itself for Indonesia in holding its commitment in taking strategic actions to support strengthening of human resources. Strengthening human resources includes the workforce which is of particular concern to ASEAN in the context of carrying out the economic integration of the ASEAN community. The workforce has a very important role and position as actors (actors) in the implementation of development, presumably it is necessary to improve the quality of Indonesian workers and their contribution to development and protect their rights and interests according to human dignity [22].

The ASEAN Declaration on the Protection and Advancement of the Rights of Migrant Workers [7], states that both receiving and sending countries will strengthen the political, economic and social pillars of the ASEAN community by advancing the full potential and dignity of migrant workers in a climate of freedom, justice and stability in accordance with laws and regulations and policies of each ASEAN member country. Receiving countries and sending countries for humanitarian reasons cooperate to resolve cases of migrant workers who through no fault of their own then result in undocumented. Receiving and sending countries must take into account the basic rights and dignity of migrant workers and members of their families who have settled with them without undermining the implementation of the laws, regulations and policies of the receiving country. Matters that are not regulated in this declaration will be interpreted as regulations of the situation of migrant workers that are not documented. However, until now, there has no specific implementing regulations that has binding force for all ASEAN member states.

The obligations of host countries for migrant workers in this Declaration, such as:[7]

a. Intensifying efforts to protect basic human rights, improve welfare and uphold the human dignity of migrant workers;

b. Work to achieve harmony and tolerance between host countries and migrant workers; 
c. Assisting access to resources and remedies through information, training and education, access to justice, and social welfare services that are appropriate and in accordance with the laws of the host country, provided they meet the legal requirements, regulations and policies of that country, bilateral agreements and multilateral treaties;

d. Promote just and appropriate employment protection, payment of wages, adequate access to employment and decent living conditions for migrant workers;

e. Provide migrant workers, who are victims of discrimination, abuse, exploitation, abuse, with adequate access to the legal and judicial systems of the receiving country;

f. Assist in carrying out consular functions to consular or diplomatic parties of the country of origin when migrant workers are arrested or put in prison or detention or detained for other reasons, under the laws and regulations of the receiving country and in accordance with the Vienna Convention on Consular Relations

This declaration in international law has non-binding legal force. For this reason, it is necessary to rearrange the obligations of ASEAN countries in providing protection to migrant workers, especially unskilled migrant workers, into a binding regional legal framework (international agreement). Heriyanto[23] argued that though the binding regulation takes a long time for consideration, then the specific clause on the legal protection for Indonesian migrant workers need to be regulated under trade agreement between Indonesia and other countries. Indonesia shall have its own position during the trade negotiation to include the protection clause for Indonesian migrant workers to their trade partner. Thus, both of the parties could have same benefits for their legal relationship.

\section{Conclusion}

Basically, everyone is guaranteed the right to be able to work anywhere with a decent wage. Every country also has an obligation for its citizens that can work freely anywhere without coercion. With this guarantee of freedom, many workers migrate to other countries to get decent work.

The ASEAN Community has agreed to implement the ASEAN Economic Community (AEC) which has been in effect since 2015 with one of its pillars providing freedom of workers in the ASEAN region to work anywhere without barriers. However, the weakness of the rule of law in ASEAN countries, especially in Indonesia, is the cause of the emergence of many unskilled migrant workers who almost dominate the labor market in ASEAN. Based on the facts on the ground, there are many problems of human rights violations faced by these unskilled migrant workers because of their inability to work.

For this reason, the implementation of regulations for migrant workers, especially those from Indonesia, needs to be closely monitored for the purpose to make them ready to be placed and work abroad. Regulations in Indonesia regarding manpower are very much deviated from in their application. There are many people in the field who falsify labor certification or send workers without being accompanied by complete labor documents.

To provide effective protection for migrant workers in the ASEAN region, it is necessary to establish minimum standards for the protection of migrant workers in ASEAN. These minimum standards include: work certification or work documents as a form of recognition for workers who have knowledge, skills and work attitudes in accordance with the required work competency standards, thus competency certification ensures that the workforce 
(certificate holder) is guaranteed to be credibility in doing a job that is their duty and responsibility, language skills, and guarantees of freedom from exploitation.

In addition, ASEAN needs to form binding regional rules (hard law) governing the protection of migrant workers who work in the ASEAN region. This protection is not only intended for skilled migrant workers but also unskilled migrant workers. So far, the ASEAN Declaration on the Protection and Advancement of the Rights of Migrant Workers has a nonbinding legal force. Binding rules are needed to ensure legal certainty for migrant workers in the ASEAN region.

\section{References}

[1] "The Asean Declaration (Bangkok Declaration) Bangkok, 8 August 1967 - ASEAN | ONE VISION ONE IDENTITY ONE COMMUNITY." https://asean.org/the-asean-declarationbangkok-declaration-bangkok-8-august-1967/ (accessed Oct. 02, 2019).

[2] General Directorate of Cooperation ASEAN, "ASEAN Vision 2020 and The Hanoi Plan of Action can ASEAN Deliver?," Jakarta, 2009.

[3] Charter of the Association of Southeast Asian Nations. 2007.

[4] A. Naerssen, Ton van; Spaan, Ernst; Zoomers, "Globalization, Migration, and Development," in Global Migration and Development, New York: Routledge, 2008.

[5] Indonesian Ministry of Trade, "Informasi Umum Masyarakat Ekonomi ASEAN: ASEAN Community in a Global Community of Nations," Jakarta, 2012.

[6] A. Development Bank, "Reinventing Mutual Recognition Arrangements: Lessons from International Experiences and Insights for the ASEAN Region."

[7] ASEAN Declaration on the Protection and Promotion of the Rights of Migrant Workers ASEAN | ONE VISION ONE IDENTITY ONE COMMUNITY. 2007.

[8] I. Organization for Migration, "IOM International Organization for Migration MIGRASI TENAGA KERJA DARI INDONESIA,” 2010.

[9] "Beragam Aduan TKI, Kekerasan Majikan hingga Tak Punya Ongkos Pulang." https://news.detik.com/berita/d-3664486/beragam-aduan-tki-kekerasan-majikan-hingga-takpunya-ongkos-pulang (accessed Oct. 02, 2020).

[10] E. R. Allen, "Analysis of Trends and Challenges in the Indonesian Labor Market," Manila, 2016.

[11] P. Permata, B. Dinar, and D. Prasetyo, Return Migration and Various Reintegration Programs for Low-Skilled Migrant Workers in Indonesia. Jakarta: The SMERU Research Institute, 2017.

[12] I. Mafruhah, T. Sarsito, and E. Gravitiani, "The Welfare of the Indonesian Migrant Workers (TKI) in the Land of a Malay Nation: A Socio-Economic Analysis," Southeast Asian J. Soc. Polit. Issues, vol. 1, no. 2, 2012.

[13] L. T. Katseli, R. E. B. Lucas, and T. Xenogiani, "Effects of Migration on Sending Countries: What do we Know?," Turin, 2006.

[14] "Convention on the Protection of the Rights of All Migrant Workers and Their Families Cultural Survival." https://www.culturalsurvival.org/publications/cultural-survivalquarterly/convention-protection-rights-all-migrant-workers-and-their (accessed Oct. 02, 2020).

[15] Convention on the Protection of the Rights of All Migrant Workers. 1990.

[16] F. Djafar, M. Khairul, and H. Hassan, "Dynamics of Push and Pull Factors of Migrant Workers in Developing Countries: The Case of Indonesian Workers in Malaysia," J. Econ. Behav. Stud., vol. 4, no. 12, pp. 703-711, 2012.

[17] P. Wicakramasekera, "Asian Labour Migration: Issues and Challenges in an Era of Globalization Piyasiri Wickramasekera," Geneva, 2002.

[18] Law No. 39 of 2004 on the Placement and Protection of Indonesian Workers Abroad. .

[19] Law Number 18 of 2017 concerning the Protection of Indonesian Migrant Workers. . 
[20] "Kritik Serikat Buruh Migran Indonesia Atas Lemahnya Pengawasan TKI Oleh BNP2TKI Tribunnews.com." https://www.tribunnews.com/nasional/2016/09/01/kritik-serikat-buruhmigran-indonesia-atas-lemahnya-pengawasan-tki-oleh-bnp2tki (accessed Oct. 02, 2020).

[21] D. Agunias, Labour Migration from Colombo Process Countries: Good Practices, Challenges, and Way Forward. Dhaka: International Organization for Migration, 2011.

[22] B. S. Sastrohadiwiryo, Manajemen tenaga Kerja Indonesia Pendekatan Administratif dan Operasional. Jakarta: Bumi Aksara, 2003.

[23] D. S. N. Heriyanto, "Klausula terkait Perlindungan terhadap Buruh Migran dan Urgensinya untuk diatur secara khusus di dalam Perjanjian Perdagangan Bebas antara ASEAN dan Uni Eropa," J. Huk. IUS QUIA IUSTUM, vol. 22, no. 3, pp. 329-345, Jul. 2015, doi: 10.20885/iustum.vol22.iss3.art1. 